\title{
HOW TO GO GREEN: a general equilibrium investigation of environmental policies for sustained growth with an application to Turkey's economy
}

\author{
Aziz Bouzaher • Sebnem Sahin • Erinç Yeldan
}

Received: 26 March 2014 / Accepted: 2 August 2014 / Published online: 11 September 2014

(C) Springer-Verlag Berlin Heidelberg 2014

\begin{abstract}
Green growth is a relatively new concept aimed at focusing attention on achieving sustainable development through the efficient use of environmental assets without slowing economic growth. This paper presents a real-world application of the concept, and identifies viable policy options for achieving a complementary environmental regulatory framework that minimizes output and employment losses. The analysis utilizes macro level data from the Turkish economy, and develops an applied general equilibrium model to assess the impact of a selected number of green policy instruments and public policy intervention mechanisms, including market-based incentives designed to accelerate technology adoption and achieve higher employment and sustainable growth patterns. Overall, our results indicate that an integrated employment and urban greening policy strategy that combines a green jobs programme with a set of earmarked tax-cum-innovation policies towards R\&D-driven growth, mainly targeted to strategic industrial sectors and agriculture, developing market economies can achieve significant reductions in gaseous emissions and urban waste while maintaining significant gains in productivity and employment.
\end{abstract}

Keywords Environmental policy · Green growth · Green jobs · Abatement · Turkey

JEL Classifications $\quad \mathrm{O} 44 \cdot \mathrm{Q} 56 \cdot \mathrm{Q} 58 \cdot \mathrm{C} 68$

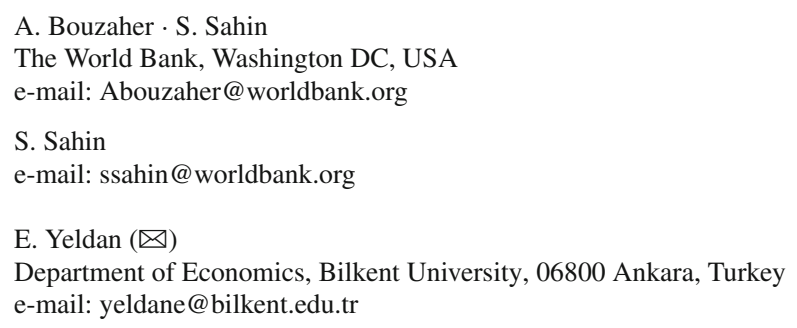




\section{Introduction}

In June 2012, leaders, researchers and civil society practitioners across the globe gathered in Rio de Janeiro to seek a renewed global consensus to maintain a sustainable path of development with due respect to the rights of future generations to live healthy and prosperous lives. This, as the UN's Millennium Development Goals Report 2013 attested, is the greatest development challenge of the 21st century.

The quest for sustainable development, made more urgent because of the uncertainties about the future climate and technology, has recently led to the realization that while economic growth has been critical in improving the standard of living of millions of people in many parts of the world, its current patterns are not only unsustainable, causing significant environmental degradation, but are also characterized by deeply inefficient production and consumption processes and management of natural resources. At the root of these problems are market and governance failures for which basic economic and regulatory instruments are available, but their systematic use as part of broader policy packages has been lacking.

All these are happening at a time when new challenges and opportunities have emerged, including the recent and still on-going food, fuel, and financial crises, and the growing global concern about the impact of climate change and the destruction of ecosystems and biodiversity. UN research (United Nations 2013; IPCC 2014) reveals that global green house gas emissions are on an upward trend, and calls for bold and decisive action. Data collected over the last two decades show that the growth in global emissions has accelerated, rising by $10 \%$ over $1990-2000$, and by $33 \%$ over 2000-2010. The rise in emissions has been mostly due to the fast growth in developing economies. In these regions $\mathrm{CO}_{2}$ emissions increased by $7 \%$ over 2009 and 2010 in contrast to $3 \%$ in the developed regions. Yet, with average emissions of 11 metric tons of $\mathrm{CO}_{2}$ per person, per year, average per capita emissions in developed/industrialized economies are still significantly higher than those in developing regions, which stand at about 3 metric tons per capita annually.

The 2013 UN report further notes that "the present dominant model of development is facing simultaneous multiple crises such as depletion of natural resources, and the market failures that have already marked the first decades of the current millennium". Accordingly, this model has been ineffective in enabling a productive and descent employment market, and has exacerbated the phenomena of climate change with its worsening effects on natural resources depletion, degradation of biodiversity, energy crisis, food security, and the cost of development. In contrast, the report underlines that the "green economy concept proposes to break away from the not very effective current model of development and move towards a more sustainable development paradigm that is merely characterized by low carbon emissions, rational use of resources and social inclusiveness". Another extensive analytical review of the literature and the state of practice by The World Bank (2012a) concludes that greening economic growth is not only necessary, but can be efficient and affordable, and "is critical to achieving sustainable development and mostly amounts to good growth policies".

In fact recent evidence reveals a burgeoning literature on the possibility of a whole set of pro-growth environmental policies. While it is generally understood that tighter environmental standards will be costly, Porter and van der Linde (1995) confirm, with 
a series of case studies, that properly designed regulation via a broad spectrum of market-based instruments such as taxes and/or cap-and-trade emissions allowances can in fact trigger innovations. This notion, later to be known as the Porter hypothesis, suggests that the evidence is more supportive of the "weak" version (i.e., stricter regulation leads to more innovation) rather than the "strong" version of the hypothesis (i.e., stricter regulation enhances business performance-or win-win) (Ambec et al. 2011; Braanlund and Lundgren 2009).

All these observations are central to green growth, a relatively new concept, which has captured the attention of policy makers, researchers and civil society organizations world wide to help design and evaluate policies that can achieve environmental sustainability efficiently, while helping to stimulate growth. This is of particular interest to fast-growing emerging market economies which are characterized by rapidly increasing environmental footprints and which seek to decouple economic growth from rising energy use and pollution generation.

While gaining a lot of traction among researcher and practitioners, and helping to reinvigorate the debate about sustainable development, the concept of green growth is still evolving, as can be seen from several definitions put forward by various organizations. ${ }^{1}$ One of the early and enduring definitions by OECD (2011) assert that "green growth means fostering economic growth and development while ensuring that natural assets continue to provide the resources and environmental services on which our well-being relies. To do this, it must catalyze investment and innovation, which will underpin sustained growth and give rise to new economic opportunities". This definition emphasizes the importance of natural assets in economic production and well-being, and therefore the need to use environmental assets efficiently. The World Bank (2012b) further emphasizes the fact that green growth policies aim to "foster sustainable development by reconciling the need for environmental sustainability for economic growth and social improvement".

This paper presents a viable, real-world application of the concept as applied to the analysis of Turkey's economy with implications for similar emerging economies. The methodological approach is undertaken within the discipline of applied general equilibrium, and develops a framework which explicitly incorporates environmental and natural resource management policy instruments at macro-economic and sectoral levels. Formally, we address the following questions: (1) what is the appropriate policy mix for sustaining green growth in an economy characterized by fiscal and external constraints and specific labor market rigidities? (2) What policy instruments can be used to maximize greening at least cost (or maximum benefit) to a developing market economy?; and (3) what is the possible mix of tax-cum-incentives policies to enhance innovation and productivity growth and to foster employment? An important premise in the analysis is that, in order to capture the general equilibrium effects of green policies, these will need to accompany ongoing growth-enhancing economic policies aimed at increasing the level of investment and its efficiency, achieving stronger employment generation and higher labor productivity, and other measures to enhance competitiveness and mitigate risks.

\footnotetext{
${ }^{1}$ See, for example, Bowen (2012), Toman (2012), OECD (2011), The World Bank (2012b).
} 
To this end, we develop and use a computable general equilibrium (CGE) model of the Turkish economy to assess the impact of a selected number of green policy instruments and public policy intervention mechanisms, including market-based incentives designed to accelerate technology adoption and achieve higher employment and sustainable growth patterns. The study spans the 2010-2030 growth trajectory of the Turkish economy, with a detailed focus on carbon and particular matter pollutants, waste and effluent pollution from both firms and households, fertilizer and water use in agriculture, and the relevant market instruments of abatement.

The paper is organized as follows: In the next section we provide a brief overview of the structure of the CGE model and the policy instruments used in the analysis. Section three is devoted to the implementation of the model to investigate various greening policy packages in a comparative setting. We conclude in the last section. A more detailed algebraic presentation of the model and its data sources are provided in two appendices to the end of the paper.

\section{General equilibrium modeling of Turkey's economy}

\subsection{Model structure and basic features}

The model is in the Walrasian tradition with optimizing agents against market signals and a simultaneous resolution of market equilibrium of commodity prices, the wage rates and the real rate of foreign exchange. "Dynamics" are integrated into the model via "sequentially" updating the static model into a medium-run of 20 years over 2010 through 2030. Economic growth is the end result of rural and urban labor population growth, investment behavior on the part of both private and public sectors, and the total factor productivity (TFP) growth performance of the Turkish economy.

The supply-side of the economy is modeled as twelve aggregated sectors. In line with our focus on strategic industrial sectors and environmental policy evaluation, the disaggregation scheme focuses on the energy sectors and other sectors with significant GHG and particulate matter pollution (commonly referred to as PM10). It further aggregates a large number of other activities that, although being far more important contributors to total gross output, are not germane to the strategic growth and greening problem.

While labor, capital and a composite of primary energy inputs (electricity, petroleum and gas, and coal), together with other intermediate inputs, are the factors of production, for modeling agricultural production activities the model further delineates between rain-fed and irrigated land. Water and fertilizer use (nitrate and phosphorus) are explicitly recognized as part of land use in agriculture production. Emissions arising both from production activities and from consumption activities are modeled within the specification of the economic sectors. An extremely important characteristic of the application of the model is that most policy scenario runs assume labor market rigidity, consistent with broad stylized facts of today's Turkish labor market. This adds to the cost of adjustment to environmental tax measures and strengthens the case for following a coordinated set of environment and growth measures for green growth, as discussed below. 
Sectoral production is modeled via a multiple-stage production technology where at the top stage, gross output is produced through a Cobb-Douglas technology defining capital $(K)$, labor $(L)$, and intermediate inputs and primary energy composite $(E N G)$ as factors of production. At a lower stage, the primary energy composite (ENG) is a constant elasticity of substitution (CES) aggregate of three major sources of energy supply: coal, petroleum and gas. The CES and Cobb-Douglas specifications incorporate the potential for technological substitution of inputs by the producer in response to relative factor prices, including impacts of tax/subsidy instruments. The CES technology allows for more substitution responses above and beyond the standard Cobb-Douglas specification where unit elasticity is implicitly assumed. In addition to these, in agriculture the model accommodates land aggregate as an additional composite factor of production. Agricultural land aggregate is further decomposed as a CES function of irrigated and rain-fed land. This decomposition is responsive to rental rates of the type of land respectively, and the relative land usage is solved endogenously by the model. Water used in irrigated land is set as a Leontief coefficient. Fertilizer use is similarly modeled as a Leontief technology as a ratio of aggregate and used. This means that fertilizer and irrigation water are used in fixed proportions with agricultural output, so reductions in either input as a consequence of environmental policy would lead to a proportionate reduction in output.

\subsection{Environmental pollution and instruments of abatement}

Two types of environmental pollutants are explicitly considered in the model:

- Air emissions in the form of carbon dioxide $\left(\mathrm{CO}_{2}\right)$ and particulate matter (PM10), from three main sources: (a) industrial processes; (b) (primary and secondary) energy usage; and (c) household energy use. These can be reduced in a variety of ways (e.g, fuel substitution, improved energy efficiency, change in activity level).

- Waste discharges (both solid and liquid), also from three main sources: (a) urban waste (formulated as a ratio of urban consumption); (b) waste from industrial processes; and waste from water use in agricultural production. The model assumes a fixed quantity of waste generation per unit of output, so as in agriculture, reductions in these waste streams through policy will lead to proportionate reductions in output.

Different allocation mechanisms of carbon dioxide are assumed based on the source of emission. Non-combustion emissions from industrial chemical processes (e.g. cement manufacturing) are hypothesized to be proportional to gross output. On the other hand, total emissions due to energy usage are generated from two sources: sectoral emissions due to combustion of primary energy fuels (coal, crude oil and gas) and sectoral emissions due to combustion of secondary energy fuels (refined petroleum).

The main greening instrument used, a pollutant tax/fee, is applied on a per-unit basis to $\mathrm{CO}_{2}$ emissions (production, intermediate input usage, and consumption, respectively) and to PM10 and waste generated. The tax revenues generated are either directly added to the revenue pool of the government budget, or directed towards a particular set of green job creation or innovation activities. 


\subsection{Data}

The model is built around a multi-sectoral social accounting matrix (SAM) of the Turkish economy based on TURKSTAT 2002 Input Output data. The I-O data is re-arranged accordingly to give a structural portrayal of intermediate flows at the intersection of the commodities row and activities column in the 12-sector 2010 macro-SAM. More details of the sectoral input-output flows of the macro SAM in correspondence with the TURKSTAT I-O data are given in Appendix 2.

\section{General equilibrium analysis of greening the Turkish economy}

We now present the results of our economic analysis on the impacts of measures to further green the Turkish economy, with a particular focus on the set of strategic sectors (automotive, construction, electronics, iron and steel, machine industry, and white goods, as well as agriculture), and consistent with the concept of "green growth" elaborated in the Sect. 1. Policy interventions are considered within two main policy scenarios:

Policy scenario 1: taxing air emissions (PM10 only), solid waste, and wastewater

The first policy scenario targets the control of solid waste and wastewater, as well as the reduction of urban air pollution (PM10 emissions) across industry and the households. This is done through the introduction of a set of tax/fee instruments to be implemented as a form of the polluter-pays principle, using the European Union standards on air quality, waste water, and solid waste.

In all, the policy package in this first scenario is made up of a total of seven new greening measures: taxes on PM10 emissions applied to industrial processes, industrial energy combustion, and private household energy consumption; and urban solid waste and waste water fees applied to industrial sectors and households.

Overall, the importance of this scenario is aimed at highlighting-among other things - the adjustment mechanisms that the Turkish economy would have to accommodate in response to a green policy of taxing environmental externalities. It can be argued that, confronted with environmental taxes that alter their own efficient production decisions and input mix, firms would initiate a host of adjustments, including the adoption of technologies that help reduce pollution intensities per unit of output produced, as well as using inputs more efficiently (e.g., energy input, water). Given the new costs imposed on production by environmental taxes, in order to remain competitive firms will look for adopting less polluting and more input-efficient technologies (e.g., the case of the iron and steel industry), as well as target gains in productivity through innovation (e.g., the case of the automotive industry).

In order to capture the expected enhancing productivity gains due to improved health from mitigating PM10 pollution, we make use of the following production 
shift:

$$
\text { adjust } \mathrm{AX}_{J}=\mathrm{e}^{\gamma_{J}} \frac{\left(\text { Pol }_{t}-\text { Pol }_{B A S E}\right)}{\text { Pol }_{B A S E}}
$$

Thus, we envisage that the Hicks-neutral productivity coefficients are adjusted upwards

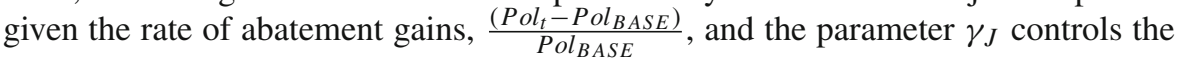
structural effectiveness of this relation. The innovation function is adapted from an earlier application by De Melo and Robinson (1992) for the case of generating productivity gains form trade externalities.

This functional form is calibrated to meet the $40 \mu \mathrm{g} / \mathrm{m}^{3} \mathrm{EU}$ standard, implying an expected gain of some $2.0 \%$ of GDP from PM10 mitigation, which is achieved by setting the structural parameter $\gamma_{J}$ at 0.002 , implying a modest productivity gain of $0.01 \%$ per annum. $^{2}$

A detailed description of the consumer behavior and public policy analysis is clearly beyond the scope of this exercise. The focus of the modeling analysis is primarily to compare the impacts on production costs and GDP of different environmental policy instruments (allowing as well for the aforementioned productivity gains); second, to illustrate how production costs from pollution taxes are larger in the presence of economic rigidities; and third, to investigate potential mitigating effects of those impacts through various public expenditure policies.

Policy scenario 2: taxing air emissions (PM10 and $\left.\mathrm{CO}_{2}\right)$, solid waste, and wastewater and using revenues for green jobs and $\mathrm{R} \& \mathrm{D}$ induced innovation

The distinguishing characteristic of the second policy scenario is the use of some of the proceeds from the carbon tax to support investment in productivity-enhancing innovation activities and employment (green jobs). Under a passive fiscal policy, the tax revenues would serve as additional public revenues to be disposed of as increased public consumption elsewhere, and/or transfers back to the private sector (including through reductions in spending of other revenues for public debt service, as in this model).

However, since the model does not allow for capturing private sector innovation choices and investments in response to green policies directly through specifying private-sector-induced innovation functions, it is done through an institutional mechanism overseen by the public sector. The model assumes that public R\&D investments generate high economic rates of return, although in practice this depends on the quality of National Innovation Systems, and the success of public innovation support schemes has varied significantly across countries (see e.g., Lerner 2009).

Moreover, in the design of the second policy scenario, we introduce the possibility of using environmental tax revenues to fund additional employment in solid waste and

\footnotetext{
${ }^{2}$ A detailed environmental health valuation based on air pollution levels and the historical growth and population trajectories suggests that without any intervention, uncontrolled growth in the PM10 emissions in Turkey will cost between 1 and $4.5 \%$ of GDP from 2010-2030. See World Bank (2013) for details of this evaluation.
} 
water pollution abatement activities. In this simple first-order calculation, government spending finances the addition of otherwise unemployed workers for these purposes given the revenue available and the fixed urban wage rate. We model the implement this policy environment via the following steps:

First, given $W^{*}$ the urban wage rate in real terms, added employment for wastewater and solid waste mitigation can be specified as:

$$
W^{*} L_{G, J}=\lambda_{J}\left(\operatorname{taxrev}_{J}\right)
$$

In (2) above, $L_{G, J}$ stands for new employment at the $j$ th category of environmental abatement activities (urban solid waste treatment across industry and households, and urban water treatment across industry and households), and taxrev $v_{J}$ refers to the corresponding tax revenues collected from the respective abatement activity- $J$. Realistically, since not all tax revenues are likely to be channeled for the new employment wage fund, through the parameter $\lambda_{J}$, a portion of the aggregate tax revenues are used for sustaining the wage fund, and the rest accrues to the public revenues as residual. Wage income from this added green employment accrues to the private disposable income.

Globally, various schemes have been used for generating "green" jobs, utilizing different types of programs and motives. For instance, the EU Commission Directorate for Employment reports that the European economies succeed in creating as much as 36.4 million jobs in activities related with climate change and pollution abatement. Programs is wind management were reportedly the source of 15.1 jobs per megawatt in manufacturing in the EU; and "green buildings" enabled 200 jobs on average per 58 million US\$ investments in the USA. Another noteworthy example is in Germany where an ecological tax reform not only raised the cost of energy leading to large energy efficiency gains, but also provided revenue which was used to reduce nonwage labor costs which helped create 250,000 jobs (The World Bank 2012b). A selection of various other sources of green employment opportunities are tabulated in Table 2.

In what follows, we further note that the new employment generated $\left(L_{G, J}\right)$ will be used for pollution abatement activities at the respective industry to reduce the PM10 and waste intensities, $\zeta_{J}$. We accomplish this through the exponential form (3) below:

$$
\operatorname{adjust} \zeta_{J}=\mathrm{e}^{-\alpha_{J} L_{G, J}}
$$

Here $\alpha_{J}$ is implemented as a calibration parameter and is taken as 1,000 . Furthermore, to capture the productivity enhancements through earmarking carbon tax revenue for $\mathrm{R} \& \mathrm{D} /$ innovation we make use of a similar functional as in (1) above and model the innovation-driven productivity gains as:

$$
\operatorname{adjust} A X_{i \in S S}=\mathrm{e}^{\varphi\left(\text { TotCO } O_{2} \text { tax Revenues }\right)} .
$$

These gains in the productivity parameter $A X_{S S}$ pertain only to the set of strategic sectors $(S S)$. In addition, innovation activities are assumed to use an abatement technology that saves on the use of energy inputs, thereby lowering the $\mathrm{CO}_{2}$ intensities arising from energy combustion similar to the specification in (3) above. Thereby, $\mathrm{CO}_{2}$ 


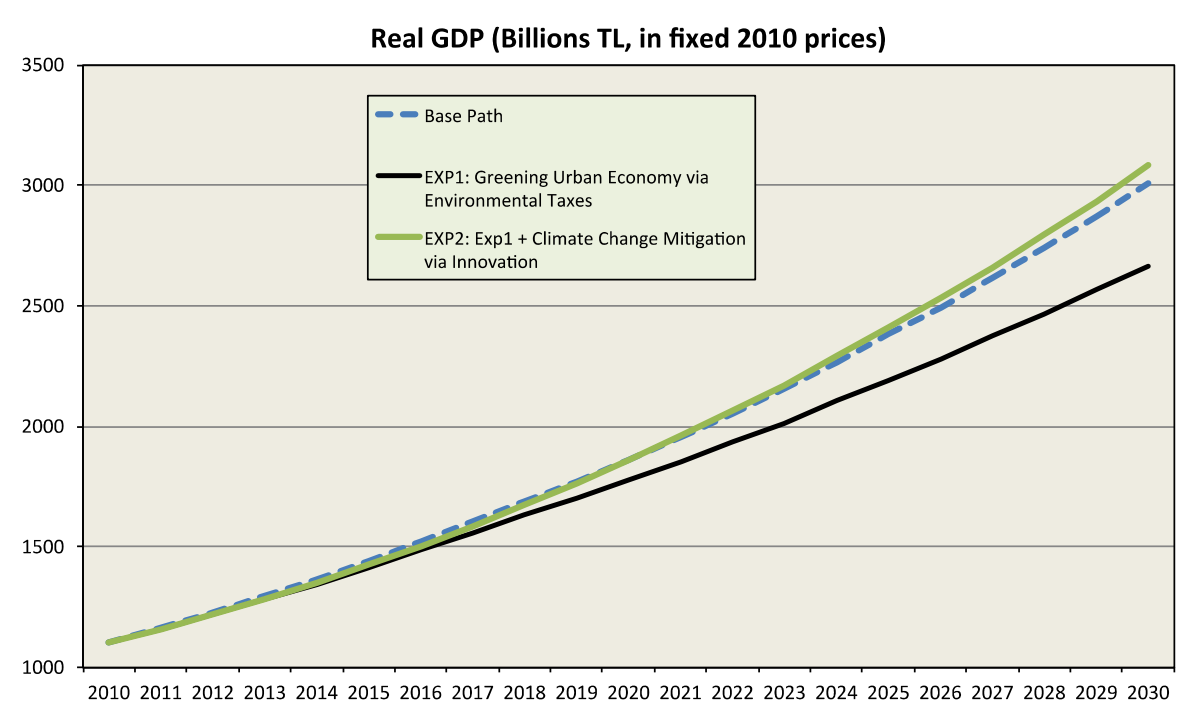

Fig. 1 Summary of policy scenarios for greening the urban economy

emission intensities in energy use (within the SS-sectors) are further reduced through innovation funded by the carbon tax revenues:

$$
\operatorname{adjust}_{i \in S S}=\mathrm{e}^{-\phi\left(\text { TotCO}_{2} \operatorname{tax} \operatorname{Revenues~}\right)} .
$$

The two key "enhancement parameters", $\varphi$ and $\phi$, are set here to calibrate the TFP gains to generate an additional gain of $0.6 \%$ over the historically observed path. ${ }^{3}$

\subsection{Results of the CGE analysis}

The results of the two policy scenarios (described above) of greening the urban economy are summarized in Fig. 1 (GDP paths), Figs. 2 and 3 (pollution emissions intensity), and Table 1 (overall summary of scenarios). ${ }^{4}$ We report three sets of results:

1. Simulation results of the urban greening scenario through combined taxes/fees on PM10 pollution, wastewater and solid waste, coupled with TFP gains from health benefits of PM10 abatement (policy scenario 1)

Under this case, the main findings indicate that taxing pollutants across industry and households leads to a significant reduction in the level of pollution intensities, consistent with the standards set forth in the relevant EU Directives.

\footnotetext{
3 The ratio of aggregate R\&D expenditures to the GDP currently stands at $0.7 \%$. The Strategy Document calls for an increase of this ratio to $3 \%$ of the GDP by 2023.

4 An important caveat is that the analysis and results presented here do not account for the transaction costs and other institutional measures needed to implement proposed greening policies, and as such, the results should be interpreted with caution and as indicative of the possible effects of the greening policies considered.
} 


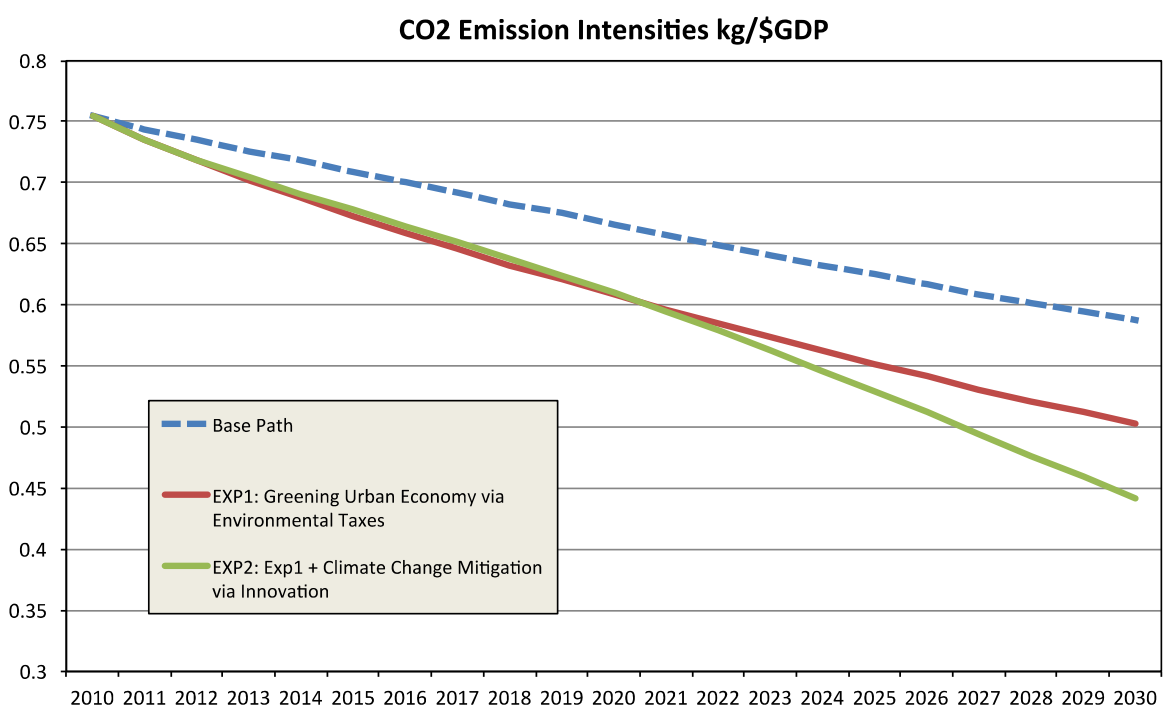

Fig. $2 \mathrm{CO}_{2}$ emission intensities

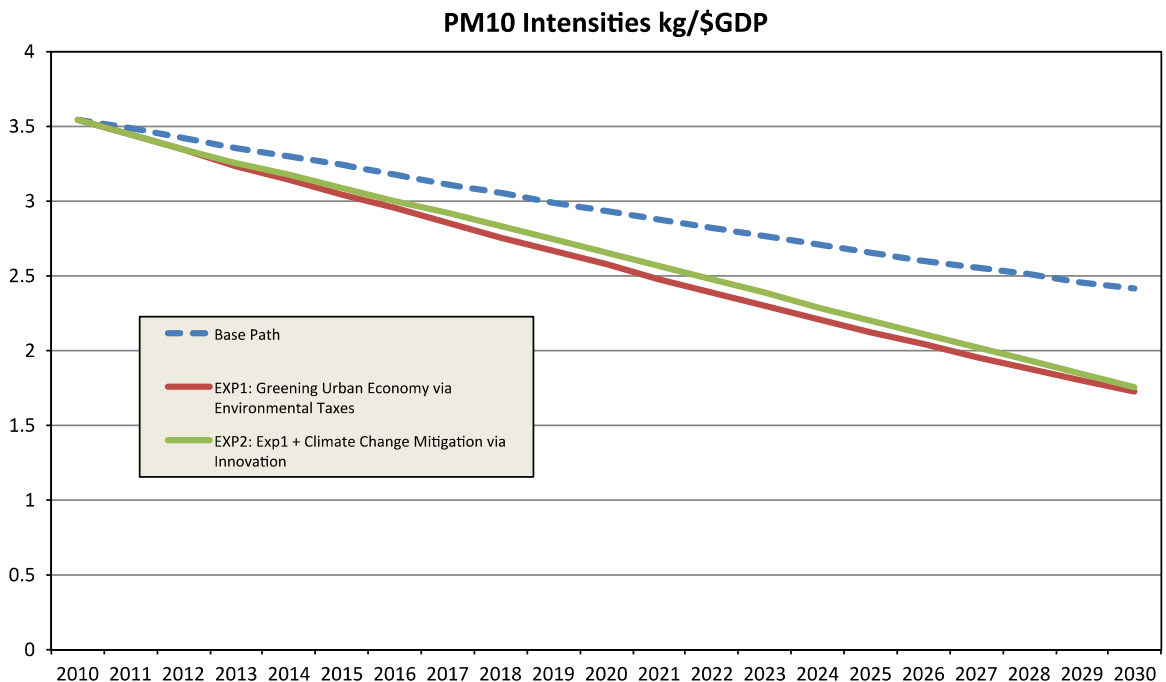

Fig. 3 PM10 intensities

We observe that this policy intervention was accompanied by a relatively significant reduction in the growth potential of GDP (10-14\% over its 2030 real value in the baseline). This is indicative of the trade-offs involved, as pollution abatement costs increase the price of doing business in the absence of any adjustments in abatement technology, in the presence of the given historical rigidities (especially in labor markets). It cannot be over-emphasized that the figures show a relative decline in GDP relative to what would be achieved by 2030 without the greening measures. However, 


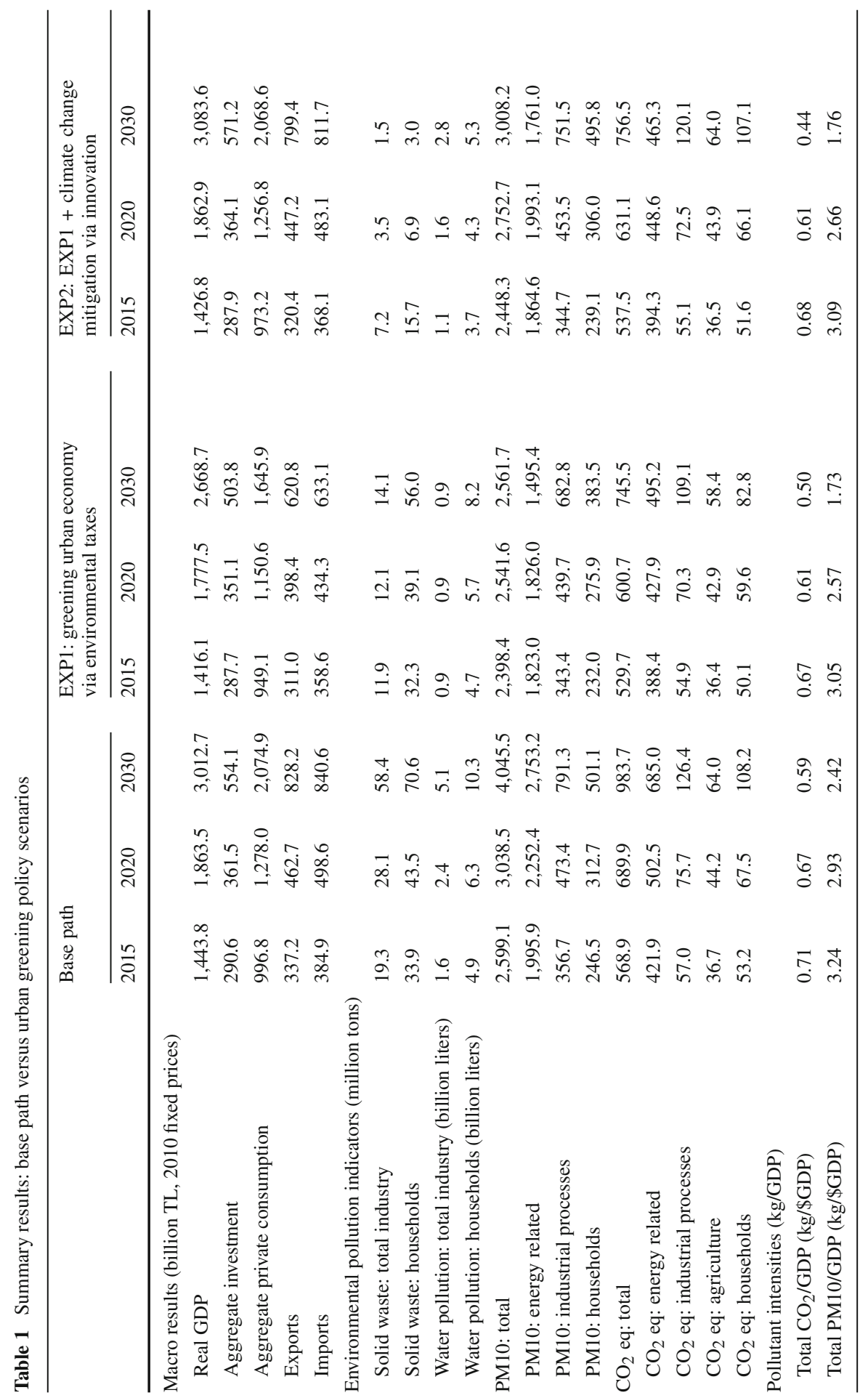




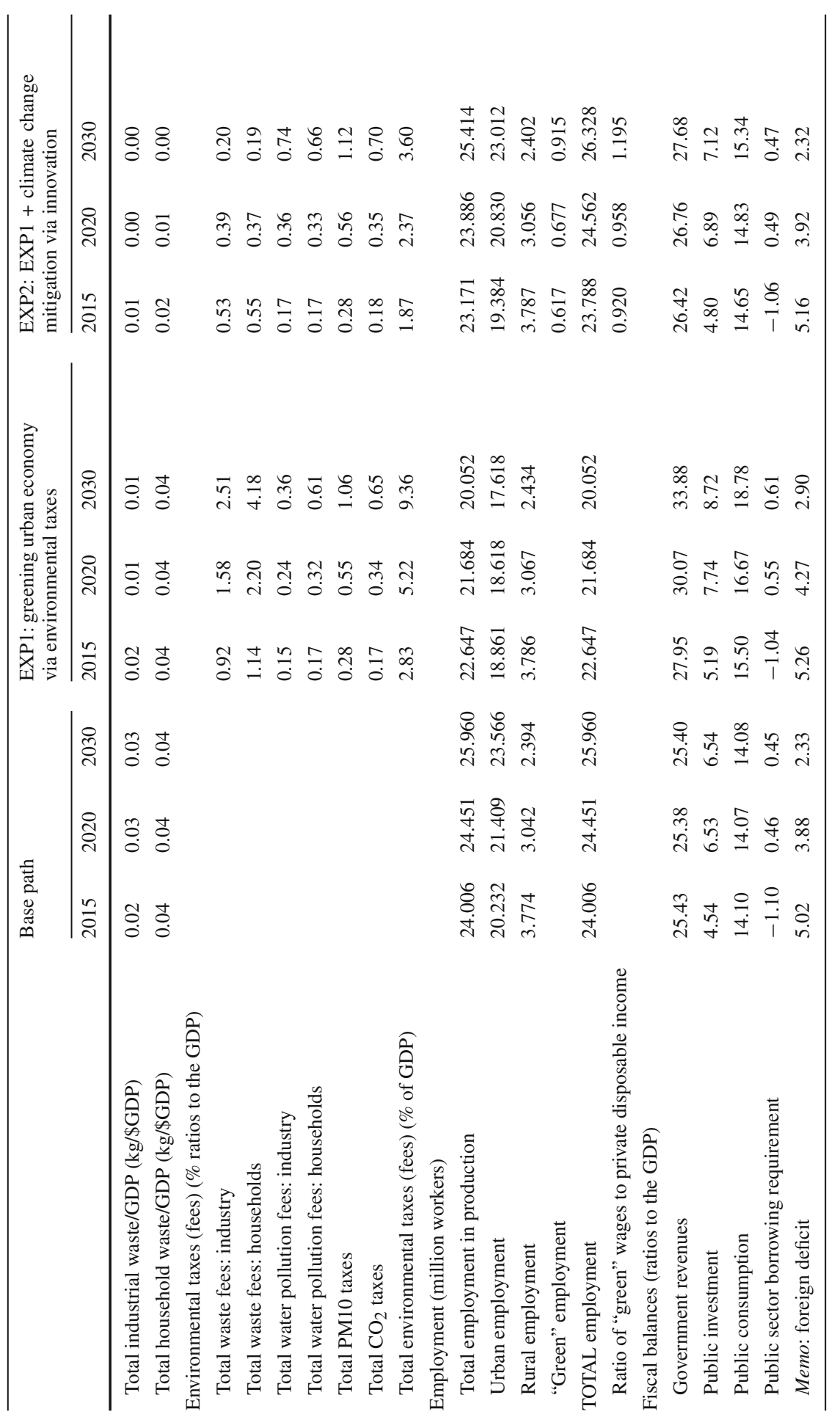




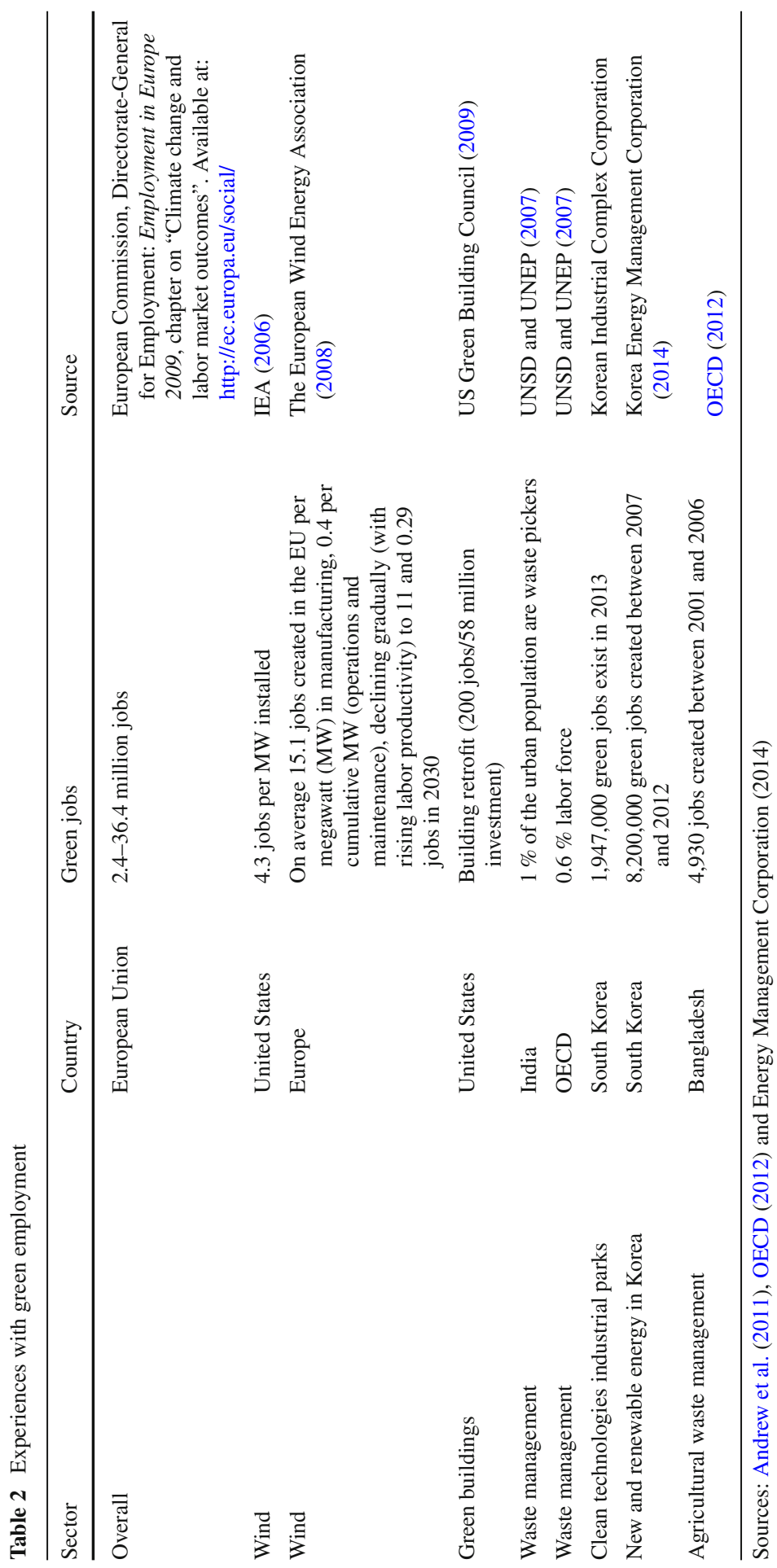


the results do not imply an absolute contraction of GDP due to environmental policy. Indeed, GDP in 2030 is still 2.4 times its 2010 base value with the greening measures (not including green jobs and the innovation-induced TFP gains), versus 1.27 times without any green measures (base path business as usual) in terms of average annual growth rates, the difference is 4.4 versus $5.0 \%$.

Clearly, while the combined impact of the wastewater, solid waste, and air pollution taxes may raise concerns for fiscally-concerned decision makers, it is important to note, however, that this GDP impact was not defined as "green GDP" which would include monetized gains of health benefits from reduced pollution, resource use efficiency, and other ecosystem benefits. And this is precisely what the new green growth paradigm is attempting to accomplish by trying to capture the positive spillovers of environmental policy across the macro-economy.

A disaggregated application of individual pollution taxes allows a differentiation of their impacts and reveals that: (a) the tax on PM10 alone has a relatively small negative impact on GDP $(<0.5 \%)$ and $3.8 \%$ pollution reduction; and when healthrelated pollution abatement productivity effects are accounted for, its overall impact is positive (+4.6\% GDP and $21 \%$ pollution reduction in 2030 compared to its baseline value); (b) taxing solid waste has the highest negative impact on GDP. This is due to the combined effects of two factors: current solid waste disposal levels are very low (thus the size of the intervention to meet the set target is very large, leading to a $44 \%$ reduction in pollution); and since these waste flows are modeled as ratios of household consumption expenditures, the waste tax thus has a direct negative effects on consumption demand. The costs would be lower if current policies in recycling and reuse have been taken into account. This would imply specifying solid waste generation a decreasing proportion of private consumption. In comparison, the economic impacts of the wastewater tax are much lower because both the target coverage and the tax rate are lower, leading to a $19 \%$ reduction in pollution in 2030 compared to its baseline value; and (c) the $\mathrm{CO}_{2}$ tax leads to a $9 \%$ abatement and a $7.4 \%$ reduction of GDP in 2030 compared to its value in the baseline. These disaggregated results indicate that air pollution and wastewater could be prioritized within the green urban scenario because of their positive health and productivity effects and their low economic impact.

2. Simulation results of the urban greening scenario through taxes/fees on PM10 pollution, wastewater and solid waste, and financing green jobs by earmarking tax revenues for that purpose (i.e., pollution taxes plus "green jobs") 5

\footnotetext{
5 As noted, for modeling purposes, green jobs/employment is defined as follows: tax revenues are collected by the government and used to hire workers at the ongoing (fixed) real wage rate from the pool of unemployed workers. These jobs are used in various greening activities (reflected in reduction of the emissions coefficients of the relevant pollutants), and the corresponding wages are added in the model as income for the single household sector. In this sense, greening increases aggregate labor employment and private consumption, which contribute positively to growth. Revenues allocated to green jobs could also be interpreted as transfers from the government to the unemployed to engage in greening activities by the private sector, thus indirectly subsidizing greener production activities by providing green labor to the companies (free of cost), and constituting an innovative case of public-private partnership. This way, the government is using pollution taxes to achieve two important objectives: reduce unemployment and improve environmental quality. Future model improvements could consider adding an additional sector (pollution abatement industry) with appropriate care to ensure that payments for this are charged against capital expenditures such that there is no double counting of capital used in production and intensity remediation.
} 
Under this case the main findings are twofold: (1) pollution intensities are significantly reduced to the levels consistent with the standards set forth in the relevant EU Directives; and (2) employment and wage income to the private sector increase. While about 600,000 new jobs are "created" in the green activities in the Turkish economy as a whole, green wages reach almost $1.5 \%$ of aggregate private disposable income. In addition, if one accounts for health-related productivity gains from PM10 abatement, the imposition of all three urban greening taxes leads to a level of GDP only $1.3 \%$ below its baseline growth path by 2030 .

3. Simulation results of an urban greening policy through taxes/fees on PM10 and $\mathrm{CO}_{2}$ emissions, as well as wastewater and solid waste, along with earmarking funds for financing green jobs and innovation expenditures (i.e., scenario of pollution tax, carbon tax, plus green jobs and $R \& D$ enhancing innovation funds)

Under this case the main finding is that when tax policy on pollution is complemented by adding a carbon tax to control $\mathrm{CO}_{2}$ emissions, and these tax revenues are further used for R\&D funding and innovation solely in the strategic sectors, the gains in productivity boost GDP to $2.4 \%$ above the base path by 2030, and result in additional employment (green jobs) of $3.5 \%$ by 2030. In addition, both solid waste (from households and industry) and wastewater are reduced by half from their respective baseline levels, and significant emission reduction is achieved (30\% reduction in PM10 and $25 \%$ reduction $\mathrm{CO}_{2}$ emissions by 2030).

Moreover, $\mathrm{CO}_{2}$ intensities per \$GDP decline below the base path trajectory. Under urban greening with taxation and jobs-financing expenditures, $\mathrm{CO}_{2}$ intensity is reduced to $0.63 \mathrm{~kg} / \$ \mathrm{GDP}$, and is further reduced with the assumed opportunities for strategic innovation to $0.44 \mathrm{~kg} /$ GDP by 2030 , on a par with the OECD average.

Finally, our modeling results also indicate that the marginal abatement cost of $\mathrm{CO}_{2}$ emissions (MAC) reaches $\$ 62 /$ ton by 2020 , then falls to $\$ 52 /$ ton by 2030 . As noted, this tax is set to meet quantitative emissions goals established under the EU Directive and Turkey's Climate Change Action Plan. On the other hand, the resulting marginal cost in 2020, is relatively higher than the numbers often encountered in the policy literature (and the lower figure for 2030 reflects that this is the model's end date versus more and tougher restrictions to be met in the further future).

When interpreting the above results, the following observations are in order:

(a) The output impacts of the first scenario depend on the technological relationships we assume in the model. Finer-grained CGE models, which incorporate sector-specific marginal abatement cost curves (MACs) and thus incorporate more detailed options for private sector reactions to pollution and environmental taxes typically find much smaller output losses (e.g., Jorgenson et al. 2012). This scenario thus demonstrates the importance of having a proper understanding of abatement technologies.

(b) Results of this analysis also depend on the recognized rigidities of the Turkish labor markets. Much of the existing rigidities are documented in the literature in a CGE modeling framework (e.g., Telli et al. 2006; Bekmez et al. 2002). Amplified adjustment costs are also found in the context of a rigid labor market in response to climate change policies in the example of South Africa (Hassan et 
al. 2008). Moreover, the findings of the scenario (with rigid labor markets and no adjustments technologically or otherwise) are in line with previous economy-wide modeling exercises of climate change in Turkey (Telli et al. 2008; Kumbaroglu 2003).

(c) Rigid structures in the labor market raise the cost of adjustment to the new taxation environment. Confronted with the wage rigidities (as formulated by assuming constant real wages in the non-agricultural labor market), producers try to respond by other forms of substitution between capital and energy inputs, as well as greater reductions in the scale of output.

(d) Relaxing the assumption of labor market rigidity can cut the estimated output losses from introducing environmental taxes by about half. A re-formulation of the "tax only" experiment with a fully flexible labor market resulted in halving the loss of the GDP compared to the base path in 2030. However, as a result the wage rate also falls by $13 \%$ over its base run value, thereby cushioning most of the taxation burden on enterprises. Further insight is provided by the case of a PM10 tax in the context of a flexible labor market, which results in a slight but positive impact on GDP compared to the case of fixed wage rate. The distributional as well as overall impacts of environmental taxes thus depend significantly on the structure of the labor market, highlighting the importance of this topic for further investigation.

(e) Finally, three overall messages emerge from this analysis: (1) the economic impact of pollution abatement costs with environmental taxes varies with sector and pollutant, but can be large under certain assumptions about limited flexibility in input substitutions; (2) productivity gains from reduced health impacts can considerably soften the cost burdens, as can the use of tax revenues for financing innovation; (3) green policies through taxation complemented by labor market policies to increase flexible adjustments will create lower economic impacts from greening. Model extensions should focus on better characterizing of the private sector reaction to environmental taxes using a detailed understanding of available technologies and their profitability, given changing relative prices to get a more finely-tuned quantitative understanding of the economic impacts of greening policies.

\section{Concluding comments}

This paper contributes to the emerging arsenal of methodologies and techniques for modeling green growth policies within a general equilibrium framework. It also presents a first cut of policy simulation results for Turkey, a fast growing middle income country in the process of negotiating accession to the European Union, and needing to get on a path of sustainable and inclusive green growth. These results point to an initial set of broader conclusions, that we summarize succinctly below.

Our analyses show that green polices that combine environmental taxes with earmarking tax revenues to stimulate innovation and green jobs can contribute to growth. This study illustrates one way of achieving such a scenario through assuming that tax revenues can be used to expand research and development capabilities and innovation 
as well as promote job creation in environmental sectors (e.g., recycling, waste water treatment, waste management, energy efficiency). These results are predicated on the fact that innovation-driven productivity gains are needed to complement environmental policies aimed at reducing the intensity of resource use and improving environmental health.

However, it is important to note that other approaches to using tax revenue to stimulate innovation and green jobs are possible. In particular, when environmental taxes are used to reduce taxes on labor and income, the impact on GDP is likely to be neutral or positive, as was the previously mentioned case for example in Germany where green taxes were used to stimulate employment through reducing the non-wage cost of labor throughout the economy.

Moreover, there is still debate among researchers and practitioners regarding what constitute "green jobs". The focus of this paper was mainly on employment created in environmental service sectors (waste management, energy efficiency, etc.), both public and private, and not on the broader employment consequences of introducing public policies to correct externalities. For example, the evidence suggests that green growth is likely to be more labor intensive than growth sustained by traditional fossil fuels. This is particularly true for renewable energy supply and energy efficiency improvements which appear to be more labor intensive, because the construction sector requires relatively unskilled labor. However, the implications of the current lower labor productivity of these activities for public finances, energy prices, and the profitability of private-sector activity, are issues that need to be carefully examined in an economy-wide context.

Finally, our study confirms that developing, emerging market economies would benefit from a mix of policy instruments better targeted at its green innovation potential. This includes not only policies to spur access to technologies and capital, but a more focused set of both supply-side 'technology-push' policies (including matching grants for collaborative early-stage technology development) and demand-side 'market-pull' policies (including prices and regulations) - that should induce green innovations across many industries. Empirical evidence shows that well-designed environmental regulations, incentives, and standards stimulate significant innovation by firms. Firm surveys in Europe show that existing or future environmental regulation is the top driver for firms to introduce environmental innovation. Similarly, international sustainability standards can help local firms upgrade their environmental practices, a form of catch-up innovation.

Acknowledgments Findings of this research rely in part on the background paper to Turkey's contribution the United Nations Conference on Sustainable Development, Rio +20, Rio de Janeiro, June 20-22, 2012. Author names are in alphabetical order, and do not necessarily reflect authorship seniority. We greatly acknowledge our indebtedness to the two anonymous referees of this journal for their critical comments and guidance. We are further grateful to Sema Bayazit, Erika Jorgenson, Lezsek Pawell, Marina Wes, Mike Toman, Kirk Hamilton, Craig Meisner, Martin Riser, Erol Çakmak, Hasan Dudu, Izzet Ari, Selen Arli, Esra Arıkan and Güneş Kolsuz for their comments and suggestions on the main research report on which this paper is based (World Bank 2013). Needless to say, none of them bear any responsibility for the views and findings outlined in the paper. Moreover, the views expressed in this paper are those of the authors, and not of their respective organizations. 


\section{Appendix 1: algebraic structure of the CGE model}

The model is in the Walrasian tradition with optimizing agents against market signals and a simultaneous resolution of market equilibrium of commodity prices, the wage rates and the real rate of foreign exchange. "Dynamics" into the model is integrated via "sequentially" updating of the static model into a medium-run of 20 years from 2010 through 2030. Economic growth is the end result of (1) rural and urban labor population growth; (2) investment behavior on the part of both private and public sectors; and (3) TFP growth performance of the Turkish economy.

The supply-side of the economy is modeled as twelve aggregated sectors. See Addendum 2 for the aggregation scheme. Labor, capital and a composite of primary energy inputs, electricity, petroleum and gas and coal, together with intermediate inputs are the factors of production. For modeling agricultural production activities, the model further accommodates rain-fed and irrigated land as additional factors. Water and fertilizer use (nitrate and phosphorus) are explicitly recognized as part of land usage in rural production.

In algebraic terms, for the non-agricultural sectors the production technology is given as follows:

$$
\begin{gathered}
X S_{i}=A X_{i}\left[K_{i}^{\lambda_{K, i}} L_{i}^{\lambda_{L, i}}\left(\prod_{j} I D^{\lambda_{I D, j, i}}\right) E N G_{i}^{\lambda_{E, i}}\right] \\
i=C O, P G, R P, E L, C E, I S, M W, E T, A U, C N, O E
\end{gathered}
$$

whereas in agriculture, production entails land aggregate $\left(N_{A}\right)$ as an additional factor of production:

$$
X S_{A}=A X_{A}\left[K_{A}^{\lambda_{K, A}} L_{A}^{\lambda_{L, i}} N_{A}^{\lambda_{N, i}}\left(\prod_{j} I D^{\lambda_{I D, j, A}}\right) E N G_{A}^{\lambda_{E, A}}\right]
$$

In Eqs. $6 \mathrm{a}$ and $6 \mathrm{~b}, A X$ is the technology level parameter, $\lambda_{K, i}, \lambda_{L, i}, \lambda_{N, i} \lambda_{E, i}$ denote the shares of capital input, the labor input, aggregate land input (only for agriculture) and the energy input in gross output in sector $i$. Under the assumption of constant returns to scale $(C R S)$ technology, for every sector $i$ :

$$
\lambda_{K, i}+\lambda_{L, i}+\lambda_{N, i}+\sum_{j} \lambda_{I D, j, i}+\lambda_{E, i}=1 .
$$

At the lower stage of the production technology, the primary energy composite is produced along a constant elasticity of substitution (CES) production function using the primary energy inputs, coal, petroleum and gas and electricity:

$$
E N G_{i}=A E_{i}\left[\kappa_{C O, i} I D_{C O, i}^{-\rho x_{i}}+\kappa_{P G, i} I D_{P G, i}^{-\rho x_{i}}+\kappa_{E L, i} I D_{E L, i}^{-\rho x_{i}}\right]^{-1 / \rho x_{i}}
$$


Under the above production technology, differentiation of the minimum cost per unit of primary energy inputs gives the sectoral demand for coal, petroleum and gas and electricity:

$$
\begin{aligned}
& \frac{I D_{C O, i}}{E N G_{i}}=\left[\frac{\kappa_{C O, i} P E G_{i}}{A E_{i}^{-p x_{i}}\left(1+C O_{2} \operatorname{tax}_{C O}+P M 10 \operatorname{tax} N_{C O}\right) P C_{C O}}\right]^{1 /\left(1+\rho x_{i}\right)} \\
& \frac{I D_{P G, i}}{E N G_{i}}=\left[\frac{\kappa_{P G, i} P E G_{i}}{A E_{i}^{-p x_{i}}\left(1+C O_{2} \operatorname{tax}_{C O}+P M 10 \operatorname{tax} N_{C O}\right) P C_{P G}}\right]^{1 /\left(1+\rho x_{i}\right)} \\
& \frac{I D_{E L, i}}{E N G_{i}}=\left[\frac{\kappa_{E L, i} P E G_{i}}{A E_{i}^{-p x_{i}}\left(1+C O_{2} \operatorname{tax}_{C O}+P M 10 \operatorname{tax} N_{C O}\right) P C_{E L}}\right]^{1 /\left(1+\rho x_{i}\right)}
\end{aligned}
$$

where $P E G$ is the cost of energy input composite, and $\mathrm{CO}_{2} \operatorname{tax} N_{j}$ and $P M 10 \operatorname{tax} N_{j}$ are the pollutant's fees (carbon, and particular matter-10 tax rates, respectively) on input $j$.

Sectoral demands for labor, capital, and energy composite and intermediate inputs arise from the profit-maximization behavior of the representative firm in each sector:

$$
\begin{aligned}
K_{i} & =\lambda_{K, i}\left[\frac{\left(1-t_{\operatorname{Pr} o d, i}-C O_{2} \operatorname{tax} P-P M 10 \operatorname{tax} P\right) P X_{i} X S_{i}}{r}\right] \\
L_{i}^{D} & =\lambda_{L, i}\left[\frac{\left(1-t_{\operatorname{Pr} o d, i}-C O_{2} \operatorname{tax} P-P M 10 \operatorname{tax} P\right) P X_{i} X S_{i}}{(1+\text { pyrltax }) \bar{w}}\right] \\
I D_{j} & =\lambda_{I D, j, i}\left[\frac{\left(1-t_{\operatorname{Pr} o d, i}-C O_{2} \operatorname{tax} P-P M 10 \operatorname{tax} P\right) P X_{i} X S_{i}}{\left(\mathrm{CO}_{2} \operatorname{tax}_{j}+P M 10 \operatorname{tax} N_{j}\right) P C_{j}}\right] .
\end{aligned}
$$

In agriculture, land aggregate is demanded in relation to its factor intensity as above:

$$
N_{A}=\lambda_{N, A}\left[\frac{\left(1-\operatorname{tax}_{A}-C O_{2} \operatorname{tax} P-P M 10 \operatorname{tax} P\right) P X_{A} X S_{A}}{R N_{A}}\right]
$$

where $R N_{A}$ is the average land rental rate. This average is obtained from the weighted average of the rental rates on irrigated land and rain-fed land:

$$
R N_{A} N_{A}=R N R F(1+\operatorname{tax} F) N R F+R N I R(1+\operatorname{tax} F+\text { feeW } N I R .
$$

In Eq. (16) $R N R F$ and $R N I R$ refer to rental rates of the rain-fed land, $N R F$, and irrigated land, $N I R$, respectively. The fee rates are on fertilizer use $(\operatorname{tax} F)$ and on water usage (feeW).

At a lower level, land aggregate is a CES composite of the irrigated and rain-fed land types:

$$
N_{A}=A N_{A}\left[\theta_{N R F, A} N R F_{A}^{-\rho_{N A}}+\left(1-\theta_{N R F, A}\right) N I R_{A}^{-\rho N A}\right]^{-1 / \rho_{N A}} .
$$


The optimal choice of the farmer towards utilization of irrigated versus rain-fed land is given from the optimizing conditions and is subject to the taxation (fees) instruments:

$$
\frac{N R F_{A}}{N I R_{A}}=\left[\frac{\theta_{N R F, A} R N I R}{\left(1-\theta_{N R F, A}\right) R N R F}\right]^{1 /\left(1+\rho_{N A}\right)} .
$$

We assume that the amount of water usage in irrigation is given by a Leontieff coefficient on the irrigated land:

$$
I R W^{D}=\omega N I R
$$

Likewise, fertilizer usage is modeled as a fixed ratio of the aggregate land:

$$
F R T^{D}=\phi(N I R+N R F)
$$

The water and fertilizer usage are to be affected by fee/subsidy instruments ( $\operatorname{tax} F$ and $\operatorname{tax} W$ ) as introduced above.

In the land markets, the rental rates of the irrigated and rain-fed land types are determined endogenousy

$$
\begin{aligned}
& N R F_{A}=N R F^{S U P} \\
& N I R_{A}=N I R^{S U P} .
\end{aligned}
$$

We specify a dualistic structure in the labor markets where rural and urban labor are differentiated. Rural labor market wages are fully flexible and the low productivity problem is revealed in low wages (rural poverty). Urban labor market is subject to real wage fixity and an endogenous unemployment mechanism is generated.

Within intertemporal dynamics, rural labor migrates into urban centers via a simple Harris-Todaro framework with migrants responding to expected urban wage rate and rural wage differences.

The amount of rural labor migrating to the urban labor market is determined through:

$$
L M I G=\mu \frac{\left(E W U-W_{A G}\right)}{W_{A G}} L S U P_{A G} .
$$

Here $W_{A G}$ is the rural labor wage rate (flexible), and $E W U$ is the expected urban wage rate. $\mu$ is an elasticity parameter used to control the responsiveness of the migration decision in response to the wage differentials. The expected urban wage rate is a weighted average of the (fixed) real urban wage rate and the sectoral employment levels in the urban sectors:

$$
E W U=W_{U R B} \sum_{i \in N o n-A g}\left(\frac{L_{i}^{D}}{L S U P_{U R B}}\right) .
$$


Given the migrated labor and supplies of both types of labor, urban labor market is cleared through quantity adjustments via unemployment:

$$
U N E M P=L S U P_{U R B}-\sum_{i \in n o A g} L D_{i}
$$

Rural labor market wages are flexible:

$$
L S U P_{A G R}=L_{A}^{D}
$$

Likewise, given the aggregate physical capital stock supply in each period, the capital market equilibrium, $\sum_{\mathrm{i}} \mathrm{K}_{\mathrm{i}}=\bar{K} S$ implies an equilibrium profit rate $r$ for the economy. Consequently, physical capital is mobile across sectors. It is the difference in sectoral profit rates that leads to the sectoral allocation of aggregate investments in withinperiod dynamics of the model.

\section{Environmental pollution and instruments of abatement}

The model accommodates two types of environmental pollution: gaseous emissions (in terms of $\mathrm{CO}_{2}$ equivalents and PM10) and waste generation.

Waste is thought to be in "solid" and "water" discharge form and is generated from

1. urban waste (to be formulated as a ratio of urban consumption);

2. waste from industrial processes, and

3. waste from water usage in agricultural production.

On the other hand, three basic sources of $\mathrm{CO}_{2}$ and $\mathrm{PMIO}$ emissions are distinguished in the model: (1) due to industrial processes, (2) due to (primary and secondary) energy usage, and (3) due to energy use of households. Total air emissions is the sum over from all these sources:

$$
\mathrm{CO}_{2} E M_{i}=\sum_{j} C \mathrm{O}_{i} E M_{j, i}^{I N M}+\mathrm{CO}_{2} E M_{i}^{E N G}+C \mathrm{O}_{2} E M_{i}^{I N D}
$$

Depending on the source of emission, we assume different allocation mechanisms of carbon dioxide. Following Gunther et al. (1992), the emissions from industrial processes is regarded to depend on the level of industrial activity, therefore is hypothesized proportional to gross output:

$$
C O_{2} E M_{i}^{I N D}=\bar{\delta}_{i} X S_{i}
$$

Total emissions due to energy usage, $\mathrm{TOTCO}_{2} \mathrm{ENG}$ are generated from two sources: sectoral emissions due to combustion of primary energy fuels (coal and petroleum and gas) and sectoral emissions due to combustion of secondary energy fuels (refined 
petroleum):

$$
T O T C O_{2} E N G=\sum_{i}\left[\sum_{j}\left(C_{2} E M_{j, i}^{I N M}+C O_{2} E M_{j, i}^{E N G}\right)\right]
$$

Under both sources, the mechanism of emission is dependent on the level of pollutantemitting inputs (energy input at primary and at secondary levels) in each sector:

$$
\begin{aligned}
C O_{2} E M_{j, i}^{E N G} & =\varpi_{\mathrm{j}, \mathrm{i}} I D_{j, i} & & j=C O, P G \\
C O_{2} E M_{j, i}^{I N G} & =\bar{\varepsilon}_{\mathrm{j}, \mathrm{i}} I D_{j, I} & & j=R P .
\end{aligned}
$$

Total emission of $\mathrm{CO}_{2}$ in the use of energy by households is given by:

$$
\mathrm{TOTCO}_{2} \mathrm{HH}=\sum_{i} \bar{\psi}_{i} C D_{i}
$$

Here, $\bar{\psi}_{i}$ is the coefficient of emissions of $\mathrm{CO}_{2}$ in private consumption $\left(C D_{i}\right)$ of the basic fuels coal $(C O)$ and refined petroleum $(R P)$ by households.

Pollutant tax/fee can serve as one of the instruments and is thought to be introduced at per tons of carbon dioxide emitted, on production, on intermediate input usage and on consumption respectively. The revenues are directly added to the revenue pool of the government budget.

PM10 emissions and instruments of environmental policy with respect to PM10 are modeled in the same manner.

\section{Income generation and demand}

Private sector is aggregated into one household. Household income comprises returns to labor input, net of social security taxes, and land rental income. As was introduced under policy scenario 2 household income is further accentuated by transfers from the green wage fund.

The net profit transfer of the enterprise income to private household is mainly composed of returns to capital as a factor of production:

$$
\begin{aligned}
& \operatorname{Etr} H H=\left(1-t_{\text {Corp }}\right) \sum_{\mathrm{i}} \mathrm{rK}_{\mathrm{i}}-\text { EERPtrROW }-N F I^{G}+\operatorname{Gtr} E E \\
& \times r^{D} \text { Dom Debt }^{G}-r^{F} e \text { ForDebt } \\
&
\end{aligned}
$$

A constant proportion of the total profit income is distributed to the rest of the world to represent the net factor income of foreigners in Turkey. In Eq. 33, GtrEE is the net transfers of the government to private enterprises, $r^{D}$ DomDebt ${ }^{G}$ is the interest income of the enterprises (banking sector) out of government domestic debt and $r^{F}$ ForDebt ${ }^{E}$ 
Table 3 Tax instruments used in the model

\begin{tabular}{ll}
\hline $\mathrm{CO}_{2}$ TAXP & $\mathrm{CO}_{2}$ tax on sectoral output \\
$\mathrm{CO}_{2}$ TAXN(I) & $\mathrm{CO}_{2}$ tax on intermediate input use \\
$\mathrm{CO}_{2}$ TAXC(I) & $\mathrm{CO}_{2}$ tax on consumer demand \\
PM10TAXP & PM10 tax on sectoral output \\
PM10TAXN(I) & PM10 tax on intermediate input use \\
PM10TAXC(I) & PM10 tax on consumer demand \\
WASTETAX & Waste tax on households \\
WASTETAXIND & Waste tax on industry \\
WSUTAXHH & Waste water tax on households \\
TAXWSUIND & Industrial waste water tax \\
TAXNITAG & Tax on fertilizer use in agricultural land \\
PROTAX(I) & Producer tax \\
SALTAX(I) & Sales tax \\
TM(I) & Tariff rate \\
TE(I) & Export tax \\
HTAX & Direct income tax \\
PYRLTAX & Payroll tax paid by employers \\
SSTAX & Social security tax (paid by formal labor) \\
CORPTAX & Corporate tax \\
TAXWSUAG & Fee on water use in irrigation \\
\hline
\end{tabular}

is the interest payments of the private enterprises for their already accumulated foreign debt. As $e$ represents the exchange rate variable, $F_{0 r B O R}{ }^{2}$ is the new foreign borrowing of the private sector in foreign exchange terms.

Private household saves a constant fraction, $s^{p}$ of its income. The residual aggregate private consumption then is distributed into sectoral components through exogenous (and calibrated) shares:

$$
C D_{i}=\operatorname{cles}_{i} \cdot \frac{P R I V C O N}{P C_{i}}
$$

where $P C_{i}$ is the composite price of product $i$ which consists of the unit prices of domestic and foreign commodities, united under the imperfect substitution assumption through an Armington specification. Aggregate public consumption is distributed into sectoral production commodities in the same manner with policy-driven public consumption shares. It is assumed that aggregate public consumption is a constant fraction of aggregate public income.

Government revenues are composed of direct taxes on wage and profit incomes and profit income from state economic enterprises. The income flow of the public sector is further augmented by indirect taxes on domestic output and foreign trade (net of subsidies), sales taxes and environmental taxes.

The set of environmental tax/fee instruments are tabulated in Table 3. 
The model follows the fiscal budget constraints closely. Current fiscal policy stance of the government is explicitly recognized as specific targets of primary (non-interest) budget balance. We regard the government transfer items to the households, to the enterprises and to the social security system as fixed ratios to government revenues net of interest payments. Then, under a pre-determined primary surplus/GDP ratio, public investment demand is settled as a residual variable out of the public fiscal accounts.

The public sector borrowing requirement, $P S B R$ then, is either financed by domestic borrowing, $\triangle \mathrm{Dom} \mathrm{Debt}^{G}$ or by foreign borrowing $\Delta e \mathrm{ForDebt}^{G}$.

\section{General equilibrium}

The overall model is brought into equilibrium through endogenous adjustments of product prices to clear the commodity markets and balance of payments accounts. With real wages being fixed in each period, equilibrium in the urban labor market is sustained through adjustments of urban employment.

Given the market equilibrium conditions, the following ought to be satisfied for each commodity $i$ :

$$
C C_{i}=C D_{i}+G D_{i}+I D P_{i}+I D G_{i}+I N T_{i}
$$

that is, the aggregate absorption (domestic supply minus net exports) of each commodity is demanded either for private or public consumption purposes, private or public investment purposes or as an intermediate good.

The model's closure rule for the savings-investment balance necessitates:

$$
P S A V+G S A V+e C A d e f=P I N V+G I N V .
$$

The CAdef in the equation above determines the current account balance in foreign exchange terms and equals to the export revenues, the remittances and private and public foreign borrowing on the revenue side and the import bill, profit transfers abroad and interest payments on the accumulated private and public debt stocks on the expenditures side:

$$
\begin{aligned}
\text { CAdef }= & \sum P_{i}^{W} E_{i}+\text { ROWtrHH }+ \text { For Bor }^{E}+\text { For Bor }^{G} \\
& -\left[\sum P_{i}^{W} M_{i}+\left(\text { trrow } \sum\left(1-t_{\text {Corp }}\right) r K_{i}\right) / e\right. \\
& \left.+r^{F} \text { ForDebt }{ }^{E}+r^{F} \text { For Debt }^{G}\right] .
\end{aligned}
$$

The private and public components of the external capital inflows are regarded exogenous in foreign exchange units. The additional endogenous variable that closes the 
Walrasian system is the private investments, PINV. Finally, the exchange rate $e$, serves as the numeriare of the system.

\section{Dynamics}

The model updates the annual values of the exogenously specified variables and the policy variables in an attempt to characterize the 2011-2030 growth trajectory of the Turkish economy. In-between periods, first we update the capital stocks with new investment expenditures net of depreciation. Labor endowments are increased by the respective population growth rates. Similarly, technical factor productivity rates are specified in a Hicks-neutral manner, and are introduced exogenously. Urban nominal wage rate is updated by the price level index which is endogenous to the system.

Finally, at this stage we account for the evolution of debt stocks. First, government's foreign borrowing is taken as a ratio to aggregate PSBR:

$$
\text { e } \text { ForBor }^{G}=(\text { gfborrat }) P S B R \text {. }
$$

Thus, government domestic borrowing becomes:

$$
\text { DomBor }=(1-\text { gfborrat }) \text { PSBR. }
$$

Having determined the equations for both foreign and domestic borrowing by the government, we establish the accumulation of the domestic and foreign debt stocks of the public sector:

$$
\begin{aligned}
\text { Dom Debt }_{t+1} & =\text { Dom Debt }_{t}+\text { Dom Bor }_{t} \\
\text { For Debt }_{t+1}^{G} & =\text { For Debt }_{t}^{G}+\text { For Bor }_{t}^{G}
\end{aligned}
$$

Similarly, private foreign debt builds up as:

$$
\text { For Debt }_{t+1}^{P}=\text { ForDebt }_{t}^{P}+\text { ForBor }_{t}^{E} \text {. }
$$

TFP increase is one of the drivers of growth; various assumptions held in greening scenarios are detailed in the main text. In the reference scenario, TFP growth is specified as:

$$
A X_{t+1}^{i}=\left(1+t f p G R_{i}\right) A X_{t}^{i}
$$

Capital and labor growth follows standard specification as:

$$
\begin{aligned}
\bar{K}_{t+1}^{S} & =(1-\text { dprt }) K_{t}^{S}+\sum_{i}\left(I D P_{i}+I D G_{i}\right) \\
\bar{L}_{t+1}^{S} & =\left(1+\text { popgr }_{t}\right) \bar{L}_{t}^{S}
\end{aligned}
$$




\section{Appendix 2: description of the CGE model calibration and base path (2011-2030)}

Data

The model is built-around a multi-sectoral SAM of the Turkish economy based on the Turkish Statistical Institute (TurkStat) 2002 Input Output (I/O) Data. The I/O data is re-arranged accordingly to give a structural portrayal of intermediate flows at the intersection of commodities row and activities column in the 12-sector 2010 macro-SAM. Table 4 provides the sectoral input-output flows of the macro SAM in correspondence with the TurkStat I/O data.

The base path 2011-2030

All alternative policy scenarios analyzed in this report are to be portrayed with respect to a base-path reference scenario. Having calibrated the parameter values, we construct

Table 4 Sectoral aggregation over TURKSTAT 2002 I/O Data

\begin{tabular}{|c|c|c|}
\hline & $\begin{array}{l}\text { Sector } \\
\text { aggregation }\end{array}$ & NACE 1.1 (code in I/O 2002 table) \\
\hline AG & Agriculture & $\begin{array}{l}\text { 01, Agriculture, hunting and related service activities } \\
02 \text {, Forestry, logging and related service activities } \\
\text { 03, Fishing, operating of fish hatcheries and fish farms; service activities } \\
\text { incidental to fishing }\end{array}$ \\
\hline $\mathrm{CO}$ & Coal & 04, Mining of coal and lignite; extraction of peat \\
\hline PG & $\begin{array}{l}\text { Crude oil and } \\
\text { natural gas }\end{array}$ & $\begin{array}{l}\text { 05, Extraction of crude petroleum and natural gas; service activities incidental } \\
\text { to oil and gas extraction excluding surveying }\end{array}$ \\
\hline $\mathrm{PE}$ & $\begin{array}{l}\text { Petroleum } \\
\text { products and } \\
\text { chemicals }\end{array}$ & 17, Manufacture of coke, refined petroleum products and nuclear fuels \\
\hline & & $\begin{array}{l}\text { 18, Manufacture of chemicals and chemical products } \\
19, \text { Manufacture of rubber and plastic products }\end{array}$ \\
\hline $\mathrm{CE}$ & Cement & 20, Manufacture of other non-metallic mineral products \\
\hline IS & Iron and steel & 21, Manufacture of basic metals \\
\hline MW & $\begin{array}{l}\text { Machinery and } \\
\text { white goods }\end{array}$ & $\begin{array}{l}\text { 22, Manufacture of fabricated metal products, except machinery and equipment } \\
\text { 23, Manufacture of machinery and equipment n.e.c. } \\
\text { 24, Manufacture of office machinery and computers }\end{array}$ \\
\hline ET & Electronics & $\begin{array}{l}\text { 25, Manufacture of electrical machinery and apparatus n.e.c. } \\
\text { 26, Manufacture of radio, television and communication equipment and } \\
\text { apparatus }\end{array}$ \\
\hline AU & Auto industry & 28, Manufacture of motor vehicles, trailers and semi-trailers \\
\hline EL & $\begin{array}{l}\text { Electricity } \\
\text { production }\end{array}$ & 32, Electricity, gas, steam and hot water supply \\
\hline $\mathrm{CN}$ & Construction & 34, Construction \\
\hline $\mathrm{OE}$ & $\begin{array}{l}\text { Other } \\
\text { economy }\end{array}$ & Others \\
\hline
\end{tabular}


a benchmark growth path for the Turkish economy for the period of 2011-2030, under the following assumptions:

- Constant technology (calibrated parameters in the production functions remain fixed).

- Exogenously determined foreign capital inflows.

- Exogenous real interest rates.

- Endogenous real exchange rate under the constraint of the current account balance.

- Constant nominal wage rate for urban labor.

- Fiscal policy in accordance with the announced policy rule of targeted primary surplus. Domestic interest rates (net costs of domestic debt servicing) are reduced over to $5 \%$ by 2015 onwards from their base values of $8 \%$ in 2010 . The ratio of primary (non-interest) surplus is initially set at 0.04 as a ratio to the GDP over 2011-2015. As a result of reduced interest costs on public domestic debt then, it is gradually reduced to 0.0 by 2020 and is kept at that level over the rest of the base path.

- No specific introduction of environmental policy action/taxation/quota.

Furthermore, population growth rate is set at $1 \%$ for rural labor until 2020 , then to be decreased to $0.7 \%$ per annum. Urban labor force is assumed to increase by $0.5 \%$ per annum. Migration elasticity parameter, $\mu$, is taken as 0.02 to match historical data on migration as reported in Çakmak et al. (2008).

Hicks-neutral productivity growth is assumed at an exogenous rate of $0.5 \%$ for agriculture and $0.8 \%$ for the non-agriculture sectors. In some of the scenarios below, we have implemented submodels to create endogeneity of TFP growth in response to health and environmental benefits.

The total available irrigated a land is assumed to expand by $0.5 \%$ per annum. Rate of depreciation for physical capital stock is set at 0.20 .

\section{References}

Ambec, S., Cohen, M.A., Elgie, S., Lanoie, P.: The porter hypothesis at 20: can environmental innovation enhance innovation and competitiveness? Resources for the Future Discussion Paper, pp. 11-01 (2011)

Bekmez, S, Genç, I., Kennedy, L.: A computable general equilibrium model for the organized and marginal labor markets in Turkey. Southwest. Econ. Rev. 29(1), 97-114 (2002)

Bowen, A.: 'Green' Growth, 'Green' Jobs and Labour Markets. Centre for Climate Change Economics and Policy, Working Paper No. 88, University of Leeds (2012)

Braanlund, R., Lundgren, T.: Environmental policy without costs? A review of the porter hypothesis. Int. Rev. Environ. Resour. Econ. 3(2), 75-117 (2009)

Çakmak, E., Dudu, H., Saraçoğlu, S., Diao, X., Roe, T., Tsur, Y.: Macro-Micro Feedback Links of Irrigation Water Managemnt in Turkey. World Bank Policy Research Working Paper No. 4781 (2008)

De Melo, J., Robinson, S.: Productivity and externalities: models of export-led growth. J. Int. Trade Econ. Dev. 1(1), 41-68 (1992)

EU Wind Energy Association: Annual Report (2008)

Hassan, R., Charles, N.: Determinants of African farmers' strategies for adapting to climate change: multinomial choice analysis. Afr. J. Agric. Res. Econ. 2(1), 1-28 (2008)

Golden Growth: Restoring the Luster of the European Economic Model (Spotlight 2: Greening Europe's Growth). Washington, DC (2012)

International Energy Agency (IEA): World Energy Statistics (2006)

IPCC: Summary for policymakers. In: Climate Change 2014: Impacts, Adaptation, and Vulnerability. Part A: Global and Sectoral Aspects. Contribution of Working Group II to the Fifth Assessment Report of 
the Intergovernmental Panel on Climateb Change. Cambridge University Press, Cambridge, pp. 1-32 (2014)

Jarvis, Andrew, Varma, Adarsh, Ram, Justin: Assessing Green Jobs Potential in Developing Countries: A Practitioner's Guide. ILO, Geneva (2011)

Jorgenson, D.W., Richard, J.G., Mun, S.H., Peter, J.W.: Energy, the Environment, and U.S. Economic Growth. In: Handbook of Computable General Equilibrium Modeling, pp. 477-552. Elsevier, Amsterdam (2012)

Korea Energy Management Corporation: Korea Green Innovation Days, Washington, DC (2014)

Kumbaroglu, Selçuk G.: Environmental taxation and economic effects: a computable general equilibrium analysis for Turkey. J. Policy Model. 25, 795-810 (2003)

Lerner: Boulevard of Broken Dreams. Harvard University Press (2009)

OECD: Green Growth and Developing Countries, Paris (2012)

OECD: Economic Survey of Turkey. http://www.oecd.org/dataoecd/42/47/33821199.pdf (2011)

Porter, M., van der Linde, C.: Toward a new conception of the environment-competitiveness relationship. J. Econ. Perspect. 9(4), 97-118 (1995)

Telli, C., Voyvoda, E., Yeldan, E.: Modeling general equilibrium for socially responsible macroeconomics: seeking for the alternatives to fight jobless growth in Turkey. METU Stud. Dev. 33(2), 255-293 (2006)

Telli, Çağatay, Voyvoda, Ebru, Yeldan, Erinç: Economics of environmental policy in Turkey: a general equilibrium investigation of the economic evaluation of sectoral emission reduction policies for climate change. J. Policy Model. 30(1), 321-340 (2008)

Toman, M.: Green Growth: An Exploratory Review. World Bank Policy Research Working Paper No. 6067, Washington, DC (2012)

World Bank: Golden Growth: Restoring the luster of the European Economic Model. The World Bank, Washington, DC (2012a)

World Bank: Inclusive Green Growth: The Pathway to Sustainable Development. The World Bank, Washington, DC (2012b)

United Nations: The sixteenth session of the intergovernmental committee experts of West Africa (inclusive green growth to accelerate socio-economic development in West Africa). Coté d'ivorie (2013)

UNSD and UNEP: Key Environmental Indicators (2007)

US Green Building Council: BioClimatic Design (2009)

World Bank: Turkey Green Growth Policy Paper: Towards a Greener Economy. Washington, DC (2013) 